\title{
KAJIAN POLA PENGOBATAN TUBERKULOSIS PARU DI PUSKESMAS RAPAK MAHANG
}

\author{
Yuriska Yudistia Ningrum, Arsyik Ibrahim, Mirhansyah Ardana, Rolan Rusli* \\ Laboratorium Riset dan Pengembangan FARMAKA TROPIS \\ Fakultas Farmasi Universitas Mulawarman \\ *email: rolan@farmasi.unmul.ac.id
}

\begin{abstract}
ABSTRAK
Penyakit tuberkulosis (TB) adalah penyakit menular langsung yang disebabkan oleh bakteri tuberkulosis (Mycobacterium tuberculosis). Penelitian ini bertujuan untuk mengetahui karakteristik, pola pengobatan dan keberhasilan pengobatan pada pasien TB paru di Puskesmas Rapak Mahang. Penelitian ini dilakukan dengan pendekatan retrospektif 57 data pasien TB paru. Hasil penelitian menunjukkan 58\% laki-laki dan $42 \%$ perempuan penderita TB. Berdasarkan usia 61,5\% terjadi pada usia dewasa, 35\% pada usia lansia, dan 3,5\% pada usia remaja. Berdasarkan kategori pengobatan $96 \%$ pasien termasuk dalam kategori 1 dan $4 \%$ termasuk dalam kategori 2 . Berdasarkan hasil pengobatan sebanyak $84 \%$ pasien sembuh, $11 \%$ pasien gagal, dan $5 \%$ pasien meninggal. Pasien meninggal tidak dilakukan observasi lanjutan mengenai penyebab kematiannya.
\end{abstract}

Kata kunci : Tuberkulosis paru, pola pengobatan, keberhasilan pengobatan

\begin{abstract}
Tuberculosis disease (TB) is direct spreads disease which caused by tuberculosis bacterial (Mycobacterium tuberculosis). The aims of this research was to know the characteristic, medical treatment pattern and the success of medicinal treatment to the medical patient pulmonary tuberculosis on Puskesmas Rapak Mahang. The research was done by 57\% retrospective approach of pulmonary tuberculosis data. The result showed that the TB sufferers were $58 \%$ male and $42 \%$ female. It were happened on ages at 61,5\% adult, 35\% elderly, and 3,5\% adolescent. The category of medicinal treatment were by $96 \%$ of category 1 and $4 \%$ of category 2. The result of medicinal treatment were $84 \%$ healed, $11 \%$ failed, and $5 \%$ pass away.
\end{abstract}

Keywords: Pulmonary tuberculosis, medicinal treatment pattern, the success of medicinal treatment

\section{PENDAHULUAN}

Tuberkulosis (TB) adalah suatu penyakit infeksi menular yang disebabkan oleh Mycobacterium tuberculosis. Jalan masuk untuk organisme Mycobacterium tuberculosis adalah saluran pernapasan, saluran pencernaan, dan luka pada kulit. Sebagian besar infeksi TB menyebar lewat udara, melalui terhirupnya droplet nukleus yang berisikan organisme basil tuberkel dari seseorang yang terinfeksi (Soemantri, 2007). 
Tuberkulosis (TB) merupakan masalah kesehatan global utama, hal ini menyebabkan jutaan pasien menderita kesakitan setiap tahunnya bersamaan dengan Human immunodeficiency virus (HIV) sebagai penyebab utama kematian. Pada tahun 2014 menurut WHO 2015 diperkirakan 9,6 juta kasus TB baru : 5,4 juta di kalangan laki-laki, 3,2 juta di kalangan perempuan dan 1,0 juta anak-anak. Ada juga 1,5 juta kematian akibat TB (1,1 juta antara orang dengan $H I V$ negatif dan 0,4 juta di antara orang dengan $H I V$ positif), dimana sekitar 890.000 adalah laki-laki, 480.000 adalah perempuan dan 140.000 anak-anak. Jumlah kematian akibat tuberkulosis adalah sangat tinggi, namun dengan diagnosis tepat waktu dan benar pengobatan, hampir semua orang dengan TB dapat disembuhkan (WHO, 2015).

Data yang tersedia untuk memperkirakan beban penyakit TB (kejadian, prevalensi, kematian) terus meningkat. Diperkirakan bahwa ada sekitar 1 juta kasus TB baru per tahun di Indonesia dua kali lipat dari sebelumnya. Di tahun 2013 penemuan kasus TB-Paru Bakteri Tahan Asam (BTA) (+) di Kalimantan Timur mencapai 1.969. Angka kesembuhan tahun 2013 sebesar $96,12 \%$.

Prevalensi dari insiden tuberkulosis paru masih sangat tinggi dan sulit diturunkan. Hal ini disebabkan karena adanya masalah medik dan non medik. Gejala akibat tuberkulosis (TB) paru adalah batuk produktif yang berkepanjangan (lebih dari 3 minggu), nyeri dada, dan hemoptisis. Gejala sistemik termasuk demam, menggigil, keringat malam, kelemahan, hilangnya nafsu makan, dan penurunan berat badan.

Penelitian ini bertujuan untuk mengetahui karakteristik, pola pengobatan, dan keberhasilan pengobatan pasien tuberkulosis paru di Puskesmas Rapak Mahang.

\section{METODE PENELITIAN}

\section{Alat dan Bahan Penelitian}

Kartu rekam medik pasien, dan lembar pengumpul data.

\section{Populasi dan sampel penelitian}

Penelitian ini dilakukan di puskesmas rapak mahang Tenggarong. Responden yang dikumpulkan pada penelitian ini sebanyak 57 orang yang selanjutnya dianalisis karakteristiknya berdasarkan usia dan jenis kelamin, pola pengobatan dan keberhasilan pengobatan.

Populasi dalam penelitian ini adalah seluruh pasien penderita tuberkulosis paru yang menjalani pengobatan di Puskesmas Rapak Mahang periode januari 2015 sampai dengan september 2016 yang masuk dalam kriteria inklusi. Penentuan sampel yang digunakan adalah dengan teknik total sampling yaitu pengambilan sampel dilakukan dengan cara menetapkan seluruh anggota sampel.

\section{Prosedur Penelitian}

Jenis penelitian ini adalah penelitian semikuantitatif yang dianalisis secara deskriptif yang kemudian diolah menjadi bentuk persentase dan disajikan dalam bentuk tabel atau diagram, pengerjaannya dilakukan dengan menggunakan rekam medik sebagai lembar pengumpul data untuk mendapatkan kesimpulan dan hasil. Serta menggunakan pendekatan secara retrospektif. 


\section{HASIL DAN PEMBAHASAN}

\section{Gambaran karakteristik pasien tuberkulosis paru}

Gambaran distribusi pasien tuberkulosis paru di Puskesmas rapak Mahang berdasarkan usia, jenis kelamin kategori pengobatan dan keberhasilan pengobatan disajikan dalam Tabel 1.

Tabel 1. Karakteristik Pasien Tuberkulosis Paru di Puskesmas Rapak Mahang

\begin{tabular}{|c|c|c|}
\hline Karakteristik & Frekuensi & Persentase (\%) \\
\hline \multicolumn{3}{|l|}{ Umur } \\
\hline$<15$ tahun & 2 & 3,5 \\
\hline 15-50 tahun & 35 & 61,5 \\
\hline$>50$ tahun & 20 & 35 \\
\hline \multicolumn{3}{|l|}{ Jenis Kelamin } \\
\hline Laki-Laki & 33 & 58 \\
\hline Perempuan & 24 & 42 \\
\hline \multicolumn{3}{|l|}{ Kategori pengobatan } \\
\hline Kategori 1 & 55 & 96 \\
\hline Kategori 2 & 2 & 4 \\
\hline \multicolumn{3}{|l|}{ Hasil Pengobatan } \\
\hline Sembuh & 48 & 84 \\
\hline Gagal & 6 & 11 \\
\hline Meninggal & 3 & 5 \\
\hline
\end{tabular}

Berdasarkan Tabel 1, diketahui bahwa pasien dengan usia 15 hingga 50 tahun baik pada perempuan ataupun laki-laki lebih banyak menderita tuberkulosis dibandingkan dengan usia lanjut dan remaja.

Insidens tertinggi tuberkulosis (TB) paru biasanya mengenai usia dewasa. Penyakit tuberkulosis paru sebagian besar terjadi pada orang dewasa yang telah mendapatkan infeksi primer pada waktu kecil dan tidak ditangani dengan baik. Usia dewasa dan diikuti usia tua merupakan kelompok yang paling sering terkena TB di Amerika Serikat tahun 2008 (CDC, 2008). Keadaan ini diduga ada hubungannya dengan tingkat aktivitas dan pekerjaan sebagai tenaga kerja produktif yang memungkinkan untuk mudah tertular dengan kuman TB setiap saat dari penderita, khususnya dengan BTA positif. Mobilitas dan interaksi sosial yang lebih tinggi pada usia 15-50 tahun yang harus bekerja untuk memperoleh pemasukan guna memenuhi kebutuhan keluarga, memungkinkan mereka untuk terinfeksi dari orang lain menjadi lebih tinggi (Godoy, 2001).

Meningkatnya kebiasaan merokok pada usia muda di negara-negara miskin juga menjadi salah satu faktor banyaknya kejadian tuberkulosis paru pada usia produktif (Kolappan, 2002).

Berdasarkan Tabel 1, juga dapat diketahui bahwa laki-laki lebih banyak menderita tuberkulosis paru dibandingkan dengan perempuan. Kejadian tuberkulosis dilaporkan lebih banyak pada laki-laki hampir di setiap negara di Dunia, terutama di negara-negara dengan pendapatan perkapita masyarakatnya masih rendah. Di setiap negara di dunia lebih banyak laki-laki dibandingkan dengan perempuan (Begum, 2001). Adanya perbedaan biologi pada laki-laki dan wanita seperti perbedaan imunitas (Bothamley, 1998).

Menurut R.E Watkins dan A.J Plant hal ini dikarenakan kebiasaan merokok pada laki-laki. Merokok diprediksikan sebagai faktor yang signifikan menyebabkan terjadinya 
perbedaan proporsi jenis kelamin terhadap kejadian TB paru di dunia (watskin, 2006). lakilaki dilaporkan lebih sering mengkonsumsi alkohol dan rokok, hal tersebut dapat mempengaruhi angka kejadian proresifitas tuberkulosis paru menjadi aktif (Lonnrorth, 2008).

Perbedaan terhadap pajanan kepada $M$. tuberculosis yang dihubungkan dengan pola kehidupan atau aktivitas interaksi sosial. Adanya perbedaan interaksi sosial dan ekonomi antara laki-laki dan perempuan, serta adanya perbedaan aktivitas sehari-hari menyebabkan kemungkinan pajanan infeksi tuberkulosis lebih banyak terhadap laki-laki (WHO, 2001).

\section{Gambaran pola pengobatan pasien tuberkulosis paru}

Secara keseluruhan hampir semua pasien tuberkulosis termasuk dalam kategori 1 sebanyak 55 orang meliputi pasien baru TB paru BTA positif, pasien TB paru BTA negatif foto toraks positif, dan pasien TB ekstra paru. Yang termasuk dalam kategori 2 sebanyak 2 orang meliputi pasien kambuh, pasien gagal, dan pasien dengan pengobatan setelah putus berobat.

BTA sputum pada pasien TB paru di puskesmas rapak mahang tidak memiliki rentang perbedaan yang jauh, tetapi hanya sebanyak 3 orang yang terdeteksi TB paru dengan BTA (+), dan 38 pasien dengan BTA (1+) sampai (3+). Faktor yang berpengaruh dalam hal ini yaitu sering terlambatnya penderita untuk memeriksakan diri sehingga bakteri telah berkembang lebih banyak.

Pemilihan kategori pengobatan disesuaikan dengan tipe pasien dan hasil pemeriksaan BTA. Hal ini menunjukkan bahwa kesadaran masyarakat untuk berobat dan memperoleh kesembuhan sudah baik. Keteraturan berobat sangat berhubungan dengan hasil pengobatan yang akan dicapai oleh pasien.

Jika dilihat berdasarkan dari dosis normal maksimum pasien cenderung lebih cepat mengalami perubahan hasil sputum dari (+) menjadi (-) kemudian pasien dengan dosis normal minimum cenderung lebih lama mengalami perubahan hasil sputum dari $(+)$ menjadi (-). Berdasarkan hal tersebut dapat diartikan bahwa dengan menggunakan dosis normal minimum pasien tetap dapat sembuh tetapi dalam jangka waktu yang lebih lama sedangkan pasien dengan penggunaan dosis normal maksimum memiliki tingkat kesembuhan lebih tinggi yang menyebabkan pasien TB akan cenderung memiliki rasa percaya diri yang tinggi dalam pengobatan sehingga akan mengikuti anjuran tenaga kesehatan dalam proses pengobatannya.

\section{Gambaran Keberhasilan Pengobatan pasien tuberkulosis paru}

Kesembuhan pasien TB paru dinilai dari perubahan pada sputum yaitu dari BTA (+) menjadi BTA (-) serta hasil foto rontgen yang menyatakan bahwa tidak ada lagi flek-flek pada paru-paru. Berdasarkan Tabel.1 diketahui bahwa mayoritas hasil akhir pengobatan ialah sembuh, sedangkan sisanya adalah gagal dan meninggal. Dikatakan sembuh apabila pasien telah menyelesaikan pengobatannya secara lengkap dan pemeriksaan sputum ulang hasilnya negatif pada akhir pengobatan. Dikatakan gagal apabila hasil pemeriksaan sputumnya tetap positif atau kembali menjadi positif pada bulan ke lima atau lebih selama pengobatan. Dikatakan meninggal apabila pasien meninggal dalam masa pengobatan karena sebab apapun.

Hasil yang didapatkan dari keseluruhan pasien yang berjumlah 57 orang yaitu sebanyak 48 orang sembuh, 6 orang gagal, 3 orang meninggal. Diketahui bahwa 2 orang diantara 48 orang yang sembuh termasuk pasien kategori 2. Berdasarkan data dilapangan 6 orang yang gagal diantaranya mengatakan bahwa penyebab kegagalan dalam pengobatan adalah tidak adanya PMO (pengawas minum obat) yang mengingatkan atau memotivasi untuk selalu minum obat tepat waktu dan sesuai dengan ketentuan. Dimana PMO berperan 
peting dalam kesembuhan pasien karena penderita selama menjalani pengobatan yang panjang kemungkinan ada rasa bosan harus setiap hari mengkonsumsi obat, sehingga dikhawatirkan terjadi putus obat atau lupa minum obat karena putus asa penyakitnya tidak sembuh-sembuh. Peran PMO diharapkan dapat mencegah putus obat karena bila terjadi untuk pengobatan selanjutnya memerlukan waktu yang lebih panjang. Terlaksananya peran PMO dengan baik yaitu untuk menjamin ketekunan, keteraturan pengobatan, menghindari putus pengobatan sebelum obat habis, mencegah ketidak sembuhan pengobatan (Rosidah, 2008).

Menurut Depkes RI 2014 Sebaiknya PMO adalah petugas kesehatan misalnya Bidan desa, perawat, pekarya, sanitarian, juru immunisasi, dan lain-lain. Bila tidak ada petugas kesehatan yang memungkinkan, PMO dapat berasal dari kader kesehatan, guru, anggota PPTI, PKK, atau tokoh masyarakat lainnya atau anggota keluarga. Untuk mengatasi hal tersebut diatas sebaiknya pihak puskesmas sebagai pusat pelayanan kesehatan masyarakat turun langsung untuk mengingatkan pasien mengkonsumsi obat sehingga dapat meminimalisir terjadinya kegagalan karena faktor PMO.

Kegagalan juga dapat disebabkan karena kurangnya kepatuhan pasien yang berpengaruh pada bakteri tuberkulosis menjadi lebih kebal sehingga penyakitnya sulit diobati, bakteri berkembang lebih banyak sehingga dapat menular ke orang lain, penderita akan membutuhkan waktu lebih lama untuk sembuh sehingga masa produktif yang hilang akan semakin banyak.

Berdasarkan data yang didapat terdapat 3 orang yang meninggal pada saat menjalani pengobatan. Penyebab kematian tidak diketahui secara pasti dan tidak dilakukan observasi lanjutan penyebab kematiannya. Menurut Depkes RI 2014 faktor risiko kematian karena TB yaitu akibat dari keterlambatan diagnosis, pengobatan yang tida adekuat, dan adanya kondisi kesehatan awal yang buruk atau penyakit penyerta.

\section{KESIMPULAN}

Pasien tuberkulosis terbanyak adalah pada usia 15-50 tahun sebesar 61,5\%, dengan kejadian terbanyak terjadi pada jenis kelamin laki-laki sebesar 58\%. Pasien yang termasuk kategori 1 sebanyak $96 \%$ kategori 2 sebanyak 4\%, 84\% pasien sembuh, 11\% pasien gagal dan $6 \%$ pasien meninggal.

\section{DAFTAR PUSTAKA}

Begum, V., de Colombani, P., Das Gupta, S., Salim, A.H., Hussain, H., Pietroni, M., Rahman, S., Pahan, D., Borgdorff, M.W. 2001. Tuberculosis and patient gender in Bangladesh: sex differences in diagnosis and treatment outcome. Int J Tuberc Lung Dis 2001; 5: 604-610

Bothamley, G. Sex And Gender In The Pathogenesis Of Infections : a Perspective From Immunology, Microbiology and Human Genetics. In : Diwan Vk, Thorson A, Winkrist A, eds. Gender and Tuberculosis Stockholm, Sweden : Nordic School Of Public Health, 1998.

CDC. Reported Tuberculosis in the United States, 2008. Atlanta, GA: U.S. Department of Health and Human Services, CDC, September 2009

Departemen Kesehatan Republik Indonesia. 2014. Pedoman Nasional Pengendalian Tuberkulosis Kementrian Kesehatan Republik Indonesia Direktorat Jenderal Pengendalian Penyakit Dan Penyehatan Lingkungan 2014. Departemen Kesehatan: Jakarta

Godoy, P., Nogues, A., Alseda, M., Manonelles, A., Artigues, A., Garcia, M. 2001. Risk factors associated to tuberculosis patients with positive sputum microscopy. Gac 
Sanit 2001;15:506-12.

Kolappan, C., Gopi, P.G. 2002. Tobacco smoking and pulmonary tuberculosis. Thorax 2002;57:964-6.

Lonnrorth, K., Williams, B.G., Stadlin, S., Jarmillo, E., Dye, C. Alcohol Use As A Risk Factor For Tuberculosis A Systemic Review BMC Public Health, 2008.

Soemantri., Irman. 2007. Keperawatan Medikal Bedah Asuhan Keperawatan Pada Pasien Dengan Sistem Pernapasan. Penerbit Salemba Medika : Jakarta

Watkins, R.E., Plant, A.J. 2006. Does smoking explain sex differences in the global tuberculosis epidemic? Epidemiol. Infect 2006;134:333-339

World Health Organization, 2015, Global Tuberculosis Report, World Health Organiszation, France

World Health Organization, 2001. A Human Rights Approach to TB : Stop TB Guidelines For Social Mobilization. World Health Organization. Geneva 